in vivo $32: 765-770(2018)$

doi:10.21873/invivo.11306

\title{
Change in Anticancer Drug Sensitivity During Neuronal Differentiation of PC12 Cells
}

\author{
HIROSHI SAKAGAMI ${ }^{1}$, YAEKO HARA ${ }^{2}$, HAIXIA SHI ${ }^{1,3}$, SOICHI IWAMA ${ }^{1}$, MIKA NAKAGAWA ${ }^{1}$, \\ HAYATO SUZUKI $^{1}$, KENTA TANAKA ${ }^{1}$, TOMOYUKI ABE ${ }^{1}$, NOBUAKI TAMURA ${ }^{1}$, HIROSHI TAKESHIMA ${ }^{1}$, \\ NORIO HORIE ${ }^{4}$, TAKAHIRO KANEKO ${ }^{4}$, HIROSHI SHIRATSUCHI ${ }^{2}$ and TADAYOSHI KANEKO ${ }^{2}$ \\ ${ }^{1}$ Meikai University School of Dentistry, Saitama, Japan; \\ ${ }^{2}$ Department of Oral Maxillofacial Surgery, Nihon University School of Dentistry, Tokyo, Japan; \\ ${ }^{3}$ Department of Traditional Chinese Medicine, Shanghai Ninth People's Hospital, \\ Shanghai Jiatong University School of Medicine, Shanghai, P.R. China; \\ ${ }^{4}$ Department of Oral and Maxillofacial Surgery, Saitama Medical Center, \\ Saitama Medical University, Saitama, Japan
}

\begin{abstract}
Background/Aim: Although there are many reports of anticancer drug-induced neurotoxicity, most previous data have been derived from neuronal cell models grown in a variety of culture conditions. This has prevented accurate assessment of the potency of their neurotoxicity and of changes in drug sensitivity of neuronal cells during differentiation. In this study, a simple neuronal differentiation induction system was established and the relative potency of neurotoxicity of eight anticancer drugs was compared during neuronal cell differentiation. Materials and Methods: Rat PC12 cells were induced to differentiate into neuronal cells by $50 \mathrm{ng} / \mathrm{ml}$ nerve growth factor in serum-free Dulbecco's modified Eagle's medium, followed by overlay of fresh nutrients at day 3, without medium change. Cell viability was determined by the 3-(4,5-dimethylthiazol-2-yl)-2,5-diphenyltetrazolium bromide method. Results: During differentiation, PC12 cells became 1.1-to more than 10,000-fold resistant to anticancer drugs. Topoisomerase inhibitors (doxorubicin, $\mathrm{SN}-38$, etoposide) were the most toxic to differentiated PC12 cells, followed by docetaxel, gefitinib, melphalan, 5-fluorouracil and methotrexate. Docetaxel showed the highest cytotoxicity against undifferentiated PC12 cells, but its cytotoxicity was dramatically reduced during differentiation. Conclusion: The
\end{abstract}

This article is freely accessible online.

Correspondence to: Hiroshi Sakagami, Meikai University Research Institute of Odontology (M-RIO), Sakado, Saitama 350-0283, Japan. Tel: +81 492792758, +81 492792787. Fax: +81 492855171, e-mail: sakagami@dent.meikai.ac.jp

Key Words: Neurotoxicity, anticancer drug, differentiation stage, PC12, NGF. present study demonstrated considerable variation in the neurotoxicity of anticancer drugs during the cell differentiation process. The present simple assay system may be useful to search for neuroprotective substances.

Recent improvement of living conditions and healthcare systems has led to increased human lifespan, allowing for the appearance of chronic diseases such as dementia (1-3). In order to search for neuroprotective substances, rat PC12 pheochromocytoma cells (4) and human SH-SY5Y neuroblastoma cells $(5,6)$ have been used as models of neurons by many investigators. However, such studies have used different culture media: RPMI 1640 (differentiated PC12) (7, 8), RPMI (PC12) (9), Dulbecco's modified Eagle's medium (DMEM) [PC12 $(10,11)$ and SH-SY5Y (12)], DMEM/F12 (1:1) (SH-SY5Y) (13, 14), MEM/F12 (SYSY5Y) (15) and DMEM/F12 + non-essential amino acids (SH-SY5Y) (16), supplemented with serum and antibiotics in most cases. We recently reported the superiority of DMEM over mixed culture medium (DMEM+Ham12), judging from growth stimulation and amino acid utilization (17).

We also recently found that paclitaxel, which causes severe side-effects during therapy such as leucopenia. thrombocytopenia, neutropenia, fatigue (18), anorexia and constipation (19), showed potent neurotoxicity against differentiated PC12 cells at nanomolar concentration (20). Based on these findings, in this study, changes in the sensitivity of PC12 cells to eight anticancer drugs during nerve growth factor (NGF)-induced neuronal cell differentiation were investigated.

\section{Materials and Methods}

Materials. The following chemicals and reagents were obtained from the indicated companies: DMEM, human recombinant NGF 

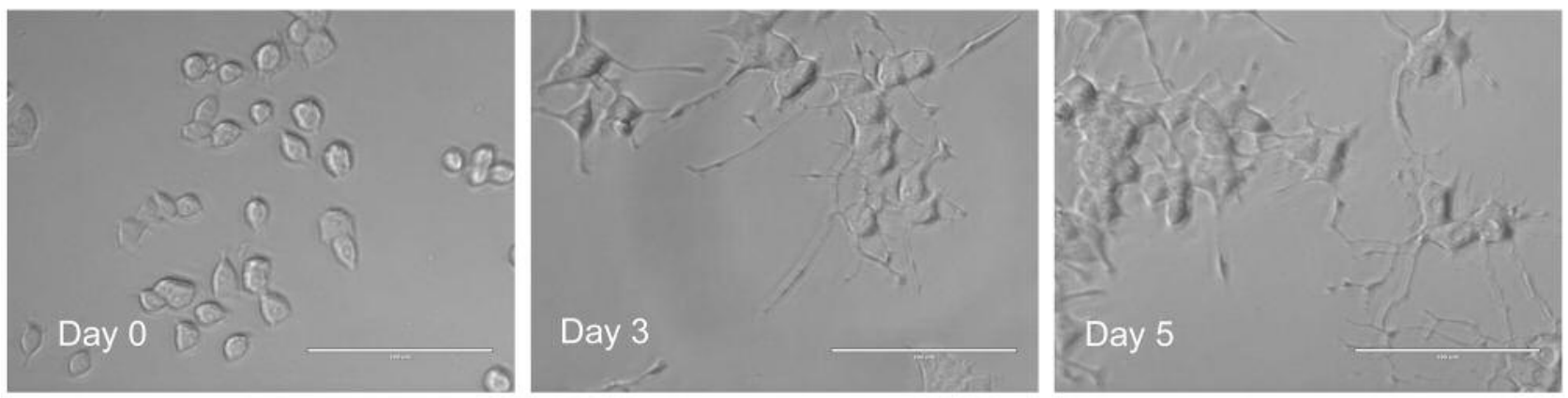

Figure 1. Induction of neurite formation in PC12 cells by nerve growth factor (NGF). PC12 cells were inoculated at $2 \times 10^{3}$ cells per microwell $\left(0.32 \mathrm{~cm}^{2}\right)$, and incubated for 2 days to allow complete cell attachment. Cells were then treated for 0 (day 0$)$ or 3 days (day 3$)$ with $50 \mathrm{ng} / \mathrm{ml} \mathrm{NGF}$. Aliquots of cells (day 3) were replenished with overlaying fresh NGF solution and incubated for another 2 days (day 5). Bar=100 $\mu \mathrm{m}$.

and dimethyl sulfoxide (DMSO) from Wako Pure Chemical Ind (Ltd., Osaka, Japan);fetal bovine serum (FBS), 3-(4,5dimethylthiazol-2-yl)-2,5-diphenyltetrazolium bromide (MTT), doxorubicin, $\mathrm{SN}-38$ (an active metabolite of irinotecan), etoposide and melphalan from Sigma-Aldrich Inc.(St. Louis, MO, USA); 5fluorouracil (5-FU) from Kyowa (Tokyo, Japan); docetaxel from Toronto Research Chemicals (NY, USA);gefitinib from LC Laboratories ${ }^{\circledR}$ (PKC Pharmaceuticals, Inc., Woburn, MA, USA), methotrexate from Nacalai Tesque, Inc. (Kyoto, Japan);96microwell plates (TPP) from Techno Plastic Products AG (Trasadingen, Swizeland)

Cell culture. PC12, a cell line derived from a pheochromocytoma of rat adrenal medulla (4), purchased from Riken Cell Bank (Tsukuba, Japan), was cultured in DMEM supplemented with $10 \%$ heat-inactivated FBS, 100 units $/ \mathrm{ml}$, penicillin $\mathrm{G}$ and $100 \mu \mathrm{g} / \mathrm{ml}$ streptomycin under a humidified $5 \% \mathrm{CO}_{2}$ atmosphere.

Induction of differentiation toward neurons. PC12 cells were inoculated at $3 \times 10^{3}$ cells per each microwell $\left(0.32 \mathrm{~cm}^{2}\right)$ and incubated for 1 day to allow complete cell attachment. The medium was completely removed by suction and replaced with $0.1 \mathrm{ml}$ of differentiation medium (serum-free DMEM containing $50 \mathrm{ng} / \mathrm{ml}$ NGF). Cells were then incubated for 3 days to induce neuronal differentiation characterized by neurite formation (referred to as day 3 cells) (Figure 1) (20). To induce more mature cells, cells were inoculated at $2 \times 10^{3}$ cells per microwell. After $24 \mathrm{~h}$, medium was replaced with $0.1 \mathrm{ml}$ of differentiation medium and incubated for 5 days [overlaid with $0.05 \mathrm{ml}$ of differentiation medium $(100 \mathrm{ng} / \mathrm{ml}$ NGF) at day 3] (referred to as day 5 cells). We adopted this overlay method since conditioned medium contains nutritional factors Differentiated cells were defined as the cells in which the extended neurites exceeded the longest diameter of each cell, assessed under a light microscope [EVOSfl; ThermoFisher Scientific, Waltham, MA, USA; described in Figure 1A of (21)].

Cytotoxicity of anticancer drugs. Day 0 cells (undifferentiated cells), day 3 and day 5 cells were overlaid with $25 \mu$ of single anticancer drug with final concentration of: $0,0.001,0.0032,0.01$, $0.032,0.1,0.32,1,3.2$ and $10 \mu \mathrm{M}$ of docetaxel, doxorubicin or $\mathrm{SN}$ 38 ; or $0,0.01,0.032,0.1,0.32,1,3.2,10,32$ and $100 \mu \mathrm{M}$ of melphalan, etoposide, 5-FU, gefitinib or methotrexate in differentiation medium. After incubation for $48 \mathrm{~h}$, the viable cell number was determined by MTT method. MTT concentration was reduced from $0.2 \mathrm{mg} / \mathrm{ml}$ to $0.1 \mathrm{mg} / \mathrm{ml}$, due to its cytotoxicity towards neuronal cells (20). The cells were incubated for $1 \mathrm{~h}$, and the formazan precipitate was dissolved in DMSO and the absorbance at $560 \mathrm{~nm}$ was measured (which reflects the relative viable cell number, more precisely cellular mitochondrial activity) with a plate leader (Infinite F 50 R;TECAN, Kawasaki, Japan).

Statistical treatment. Experimental values are expressed as the mean \pm standard deviation (SD) of six determinants. Statistical analysis was performed using Student's $t$-test. A $p$-value of less than 0.05 was considered significant.

\section{Results}

Drug-sensitivity of undifferentiated PC12 cells. Docetaxel showed potent cytotoxicity towards undifferentiated PC12 cells (Figure 2). The $50 \%$ cytotoxic concentration of docetaxel $\left(\mathrm{CC}_{50}\right)$ was below $1 \mathrm{nM}$ in all three experiments (Exp.1, 2 and 3 in Figure 1). The potency of neurotoxicity in undifferentiated PC12 cells was in the order: docetaxel $>$ SN-38 >doxorubicin >etoposide >melphalan >5-FU $>$ gefitinib $>$ methotrexate (day 0 in Table I).

Drug sensitivity of differentiated PC12 cells. Neuronal differentiation was induced by addition of $50 \mathrm{ng} / \mathrm{ml} \mathrm{NGF}$ in serum-free DMEM (Figure 1). PC12 cells pretreated for 3 days with NGF showed prominent elongation of neurites, characteristic of neuronal cells (Figure 2). Day 3 PC12 cells showed strong resistance to anticancer drugs, as evidenced by elevated $\mathrm{CC}_{50}$ values compared with undifferentiated cells. Doxorubicin showed the highest cytotoxicity, followed by $\mathrm{SN}-38$, docetacel $>$ etoposide $>$ gefitinib $>$ melphalan $>5$ FU and methotrexate (day 3 in Table I).

PC12 cells pretreated for 5 days with NGF showed similar magnitudes of resistance to anticancer drugs. Doxorubicin 

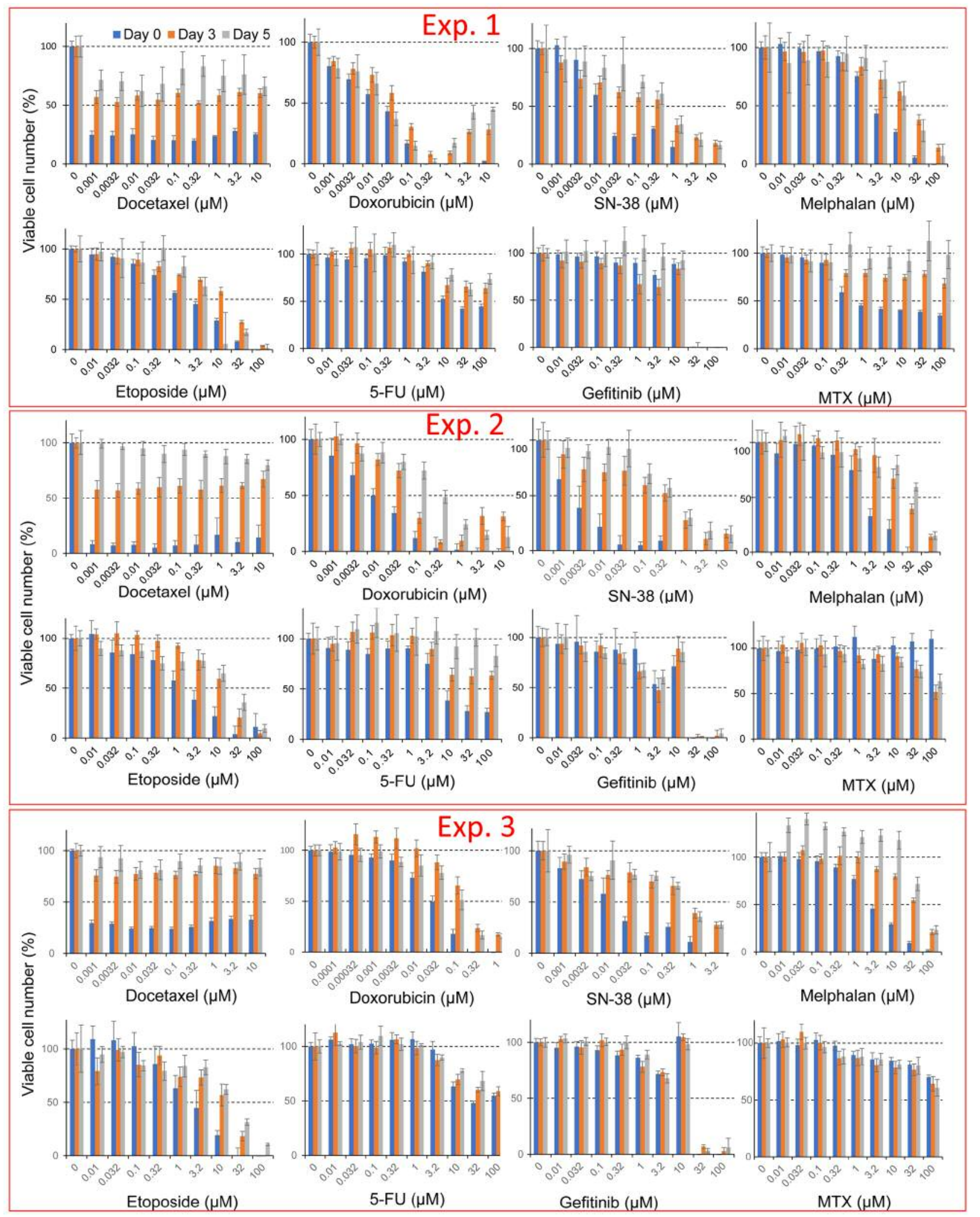

Figure 2. Cytotoxicity of eight anticancer drugs against undifferentiated and differentiated PC12 cells. PC12 cells (day 0, day 3, day 5) were treated for $48 \mathrm{~h}$ with the indicated concentrations of each anticancer drug, and viable cell number was determined by MTT method. Each value represents mean \pm S.D. from six determinations. 
Table I. Anticancer drug sensitivity of PC12 cells during nerve growth factor (NGF)-induced differentiation. PC12 cells were induced to neuronal differentiation by treatment for 3 or 5 days with $50 \mathrm{ng} / \mathrm{ml} \mathrm{NGF}$ in serum-free Dulbecco's modified Eagle's medium, and then treated for further $48 \mathrm{~h}$ with different concentrations of anticancer drugs in six determinations. The $50 \%$ cytotoxic concentration $\left(C C_{50}\right)$ was determined from the dose-response curve. The experiments (Exp) were performed three times to check reproducibility.

\begin{tabular}{|c|c|c|c|c|c|c|c|c|c|c|c|c|}
\hline \multirow[b]{2}{*}{ Agent } & \multirow[b]{2}{*}{ Cells } & \multicolumn{6}{|c|}{$\mathrm{CC}_{50}(\mu \mathrm{M})$} & \multicolumn{5}{|c|}{ Viable cell number of control $\left(\mathrm{A}_{560}\right)$} \\
\hline & & Exp. 1 & Exp. 2 & Exp. 3 & Mean & $\mathrm{SD}$ & (n-fold) & Exp. 1 & Exp. 2 & Exp. 3 & Mean & $\mathrm{SD}$ \\
\hline \multirow[t]{3}{*}{ Docetaxel } & Day 0 & $<0.001$ & $<0.001$ & $<0.001$ & $<0.001$ & & 1.0 & 0.425 & 0.118 & 0.24 & 0.261 & 0.155 \\
\hline & Day 3 & $>10$ & $>10$ & $>10$ & $>10$ & & $>10000$ & 0.399 & 0.456 & 0.585 & 0.480 & 0.095 \\
\hline & Day 5 & $>10$ & $>10$ & $>10$ & $>10$ & & $>10000$ & 0.063 & 1.17 & 0.609 & 0.614 & 0.554 \\
\hline \multirow[t]{3}{*}{ DXR } & Day 0 & 0.021 & 0.01 & 0.031 & 0.021 & 0.01 & 1.0 & 0.37 & 0.0938 & 0.234 & 0.233 & 0.138 \\
\hline & Day 3 & 0.051 & 0.068 & 0.18 & 0.10 & 0.07 & 4.8 & 0.378 & 0.46 & 0.608 & 0.482 & 0.117 \\
\hline & Day 5 & 0.022 & 0.31 & 0.106 & 0.15 & 0.15 & 7.1 & 0.11 & 1.28 & 0.682 & 0.691 & 0.585 \\
\hline \multirow[t]{3}{*}{ SN-38 } & Day 0 & 0.016 & 0.0023 & 0.017 & 0.01 & 0.01 & 1.0 & 0.44 & 0.117 & 0.334 & 0.297 & 0.165 \\
\hline & Day 3 & 0.497 & 0.38 & 0.72 & 0.53 & 0.17 & 45.2 & 0.383 & 0.418 & 0.659 & 0.487 & 0.150 \\
\hline & Day 5 & 0.597 & 0.5 & 0.68 & 0.59 & 0.09 & 50.3 & 0.079 & 1.01 & 0.713 & 0.601 & 0.476 \\
\hline \multirow{3}{*}{ Melphalan } & Day 0 & 2.72 & 2.31 & 2.9 & 2.64 & 0.30 & 1.0 & 0.431 & 0.104 & 0.318 & 0.284 & 0.166 \\
\hline & Day 3 & 21 & 23.4 & 40.2 & 28.20 & 10.46 & 10.7 & 0.346 & 0.44 & 0.622 & 0.469 & 0.140 \\
\hline & Day 5 & 16.6 & 45.9 & 62.5 & 41.67 & 23.24 & 15.8 & 0.06 & 1.001 & 0.558 & 0.540 & 0.471 \\
\hline \multirow[t]{3}{*}{ Etoposide } & Day 0 & 2.2 & 1.88 & 2.6 & 2.23 & 0.36 & 1.0 & 0.406 & 0.0892 & 0.217 & 0.237 & 0.159 \\
\hline & Day 3 & 15.7 & 15.6 & 13.9 & 15.07 & 1.01 & 6.8 & 0.435 & 0.403 & 0.582 & 0.473 & 0.095 \\
\hline & Day 5 & 4.75 & 21.4 & 18.5 & 14.88 & 8.89 & 6.7 & 0.114 & 1.26 & 0.735 & 0.703 & 0.574 \\
\hline \multirow[t]{3}{*}{ 5-FU } & Day 0 & 16 & 7.9 & 29.1 & 17.67 & 10.70 & 1.0 & 0.43 & 0.129 & 0.265 & 0.275 & 0.151 \\
\hline & Day 3 & $>100$ & $>100$ & $>100$ & $>100$ & & $>5.7$ & 0.333 & 0.49 & 0.617 & 0.480 & 0.142 \\
\hline & Day 5 & $>100$ & $>100$ & $>100$ & $>100$ & & $>5.7$ & 0.072 & 0.958 & 0.697 & 0.576 & 0.455 \\
\hline \multirow[t]{3}{*}{ Gefitinib } & Day 0 & 19.5 & 15.1 & 20.4 & 18.33 & 2.84 & 1.0 & 0.391 & 0.0833 & 0.252 & 0.24 & 0.15 \\
\hline & Day 3 & 18.7 & 19.8 & 22.2 & 20.23 & 1.79 & 1.1 & 0.371 & 0.498 & 0.589 & 0.49 & 0.11 \\
\hline & Day 5 & 19.7 & 19.2 & 21.1 & 20.00 & 0.98 & 1.1 & 0.091 & 1.27 & 0.756 & 0.71 & 0.59 \\
\hline \multirow[t]{3}{*}{ MTX } & Day 0 & 0.76 & $>100$ & $>100$ & $>67$ & & 1.0 & 0.37 & 0.0803 & 0.257 & 0.24 & 0.15 \\
\hline & Day 3 & $>100$ & $>100$ & $>100$ & $>100$ & & 1.5 & 0.392 & 0.396 & 0.592 & 0.46 & 0.11 \\
\hline & Day 5 & $>100$ & $>100$ & $>100$ & $>100$ & & 1.5 & 0.101 & 1.27 & 0.72 & 0.70 & 0.58 \\
\hline
\end{tabular}

DXR, Doxorubicin; 5-FU, 5-fluorouracil; MTX, methotrexate; SD, standard deviation.

was again the most cytotoxic, followed by SN-38, docetacel >etoposide > gefitinib >melphalan $>5$-FU and methotrexate (day 5 in Table I).

Relationship between drug-sensitivity and cell density. When the $\mathrm{CC}_{50}$ value (left column in Table I) was plotted against the control cell density at the cell harvesting time (right column in Table I), it became clear that cells had already acquired drug resistance in the first 3 days, and kept a plateau level of sensitivity from day 3 to day 5 (Figure 3 ). Cell resistance to docetaxel was the most remarkable (more than 10,000-fold at day 3; more than 10,000-fold at day 5), followed by $\mathrm{SN}-38$ $>$ melphalan $>$ etoposide $>5$-FU $>$ doxorubicin $>$ methotrexate $>$ gefitinib (left column in Table I).

\section{Discussion}

The present study demonstrated for the first time that PC12 cells acquired resistance to many anticancer drugs during neuronal differentiation induced by NGF, and the drug sensitivity reached a plateau at 3 days after NGF treatment.

The most dramatic change in sensitivity was observed with docetaxel, for which cells acquired more than 10,000-fold resistance during differentiation. Mode of growth inhibition was different between taxanes and other agents (doxorubicin, SN-38, melphalan and etoposide). Taxanes, such as doxetaxel (Figure 2) and paclitaxel (21), were cytostatic, whereas the latter compounds were cytotoxic. Taxanes are well known to inhibit calcium-induced depolymerization of tubulin and thus 


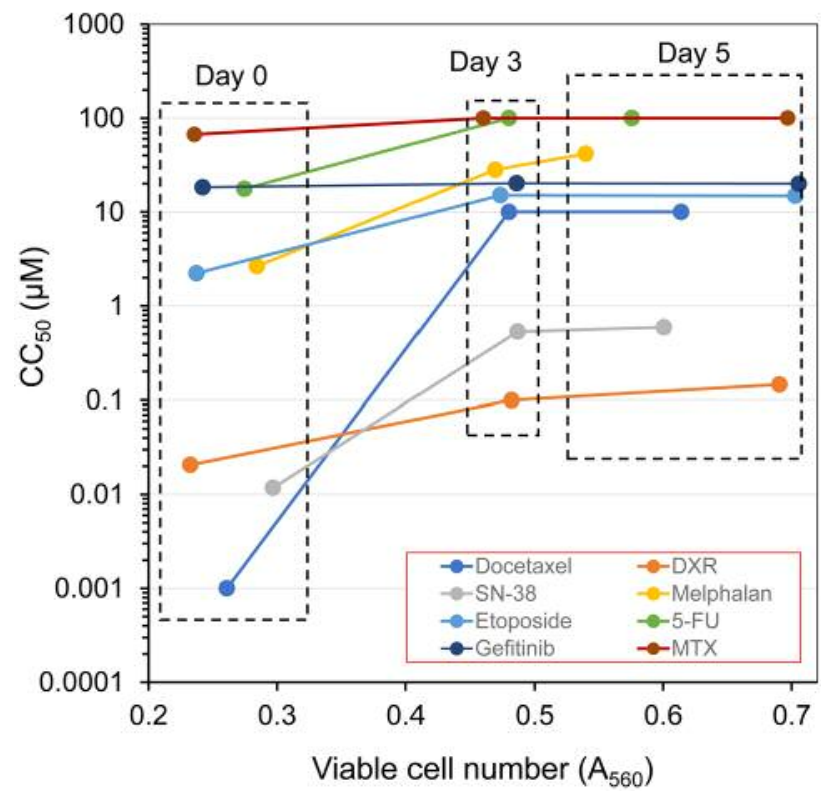

Figure 3. Relationship between cell density and viability. Drug sensitivity [evaluated by $50 \%$ cytotoxic concentration $\left(C C_{50}\right)$ value in left column of Table I] was plotted against cell density $\left(A_{560}\right)$ of control cells, measured at the time of cell harvest (determined by the MTT method) (right column of Table I).

block the progression of mitosis (22). Our preliminary data indicate that differentiating PC12 cells grow very well even in the absence of serum, when NGF was provided (unpublished data), suggesting autocrine production of growth factors. This observation was the basis for the present simplified overlay method of neuronal differentiation. We avoided medium changes, which may cause some detachment of cells from the plate. It remains to be investigated whether the acquirement of docetaxel resistance during differentiation may be due to the production of such growth factors by differentiating neuronal cells, or the formation of a tight neurite network.

The present simple assay system may be useful for studies seeking neuroprotective substances and investigating the interaction between neuronal cells and other cells.

\section{Conflicts of Interest}

The Authors confirm that there are no known conflicts of interest associated with this publication and there was no significant financial support for this work that could have influenced its outcome.

\section{Acknowledgements}

This work was partially supported by KAKENHI from the Japan Society for the Promotion of Science (JSPS) (16K11519).

\section{References}

1 Parra-Vidales E, Soto-Pérez F, Perea-Bartolomé MV, FrancoMartín MA and Muñoz-Sánchez JL: Online interventions for caregivers of people with dementia: a systematic review. Actas Esp Psiquiatr 45(3): 116-126, 2017.

2 Ostan R, Monti D, Gueresi P, Bussolotto M, Franceschi C and Baggio G: Gender, aging and longevity in humans: an update of an intriguing/neglected scenario paving the way to a genderspecific medicine. Clin Sci (Lond) 130(19): 1711-1725, 2016.

3 Kroneman M, Boerma W, van den Berg M, Groenewegen P, de Jong J and van Ginneken E: Netherlands: Health system review. Health Syst Transit 18(2): 1-240, 2016.

4 Greene LA and Tischler AS: Establishment of a noradrenergic clonal line of rat adrenal pheochromocytoma cells which respond to nerve growth factor. Proc Natl Acad Sci USA 73(7): 2424-2428, 1976.

5 Biedler JL, Helson L and Spengler BA: Morphology and growth, tumorigenicity, and cytogenetics of human neuroblastoma cells in continuous culture. Cancer Res 33(11): 2643-2652, 1973.

6 Biedler JL, Roffler-Tarlov S, Schachner M and Freedman LS: Multiple neurotransmitter synthesis by human neuroblastoma cell lines and clones. Cancer Res 38: 3751-3757, 1978.

7 Xu P, Li Z, Wang H, Zhang X and Yang Z: Triptolide Inhibited cytotoxicity of differentiated PC12 cells induced by amyloid- $\beta 25-$ 35 via the autophagy pathway. PLoS One 10(11): e0142719, 2015.

8 Tsai YC, Lee YM, Lam KK, Lin JF, Wang JJ, Yen MH and Cheng PY: The role of heat shock protein 70 in the protective effect of YC-1 on $\beta$-amyloid-induced toxicity in differentiated PC12 cells. PLoS One 8(7): e69320, 2013.

9 Muthaiyah B, Essa MM, Chauhan V and Chauhan A: Protective effects of walnut extract against amyloid beta peptide-induced cell death and oxidative stress in PC12 cells. Neurochem Res 36(11): 2096-2103, 2011.

$10 \mathrm{Ma} \mathrm{R}, \mathrm{Hu} \mathrm{J}$, Huang $\mathrm{C}$, Wang $\mathrm{M}$, Xiang $\mathrm{J}$ and $\mathrm{Li} \mathrm{G}$ : JAK2/STAT5/BCL-xL signalling is essential for erythropoietinmediated protection against apoptosis induced in PC12 cells by the amyloid $\beta$-peptide $\mathrm{A} \beta_{25-35}$. Br J Pharmacol 171(13): 3234$3245,2014$.

11 Ai Z, Li C, Li L and He G: Resveratrol inhibits $\beta$-amyloidinduced neuronal apoptosis via regulation of p53 acetylation in PC12 cells. Mol Med Rep 11: 2429-2434, 2015.

12 Hettiarachchi N, Dallas M, Al-Owais M, Griffiths H, Hooper N, Scragg J, Boyle J and Peers C: Heme oxygenase-1 protects against Alzheimer's amyloid- $\beta_{1-42}$-induced toxicity via carbon monoxide production. Cell Death Dis 5: e1569, 2014.

13 Zhang Y, Jiao G, Song C, Gu S, Brown RE, Zhang J, Zhang P, Gagnon J, Locke S, Stefanova R, Pelletier C, Zhang Y and Lu $\mathrm{H}$ : An extract from shrimp processing by-products protects $\mathrm{SH}-$ SY5Y cells from neurotoxicity induced by A $\beta 25-35$. Mar Drugs 15(3): 83, 2017.

14 Cameron RT, Quinn SD, Cairns LS, MacLeod R, Samuel ID, Smith BO, Carlos Penedo J and Baillie GS: The phosphorylation of Hsp20 enhances its association with amyloid- $\beta$ to increase protection against neuronal cell death. Mol Cell Neurosci 61: 4655, 2014.

15 Wang Q, Yu X, Patal K, Hu R, Chuang S, Zhang G and Zheng $\mathrm{J}$ : Tanshinones inhibit amyloid aggregation by amyloid- $\beta$ peptide, disaggregate amyloid fibrils, and protect cultured cells. ACS Chem Neurosci 4(6): 1004-1015, 2013. 
16 Chilumuri A and Milton NG: The role of neurotransmitters in protection against amyloid- $\beta$ toxicity by KISS- 1 overexpression in SH-SY5Y neurons. ISRN Neurosci 2013: 253210, 2013.

17 Sakagami H, Suzuki R, Shirataki Y, Iwama S, Nakagawa M, Suzuki H, Tanaka K, Tamura N and Takeshima H: Re-evaluation of culture condition of PC12 and SH-SY5Y cells based on growth rate and amino acid consumption. In Vivo 31(11): 1089$1095,2017$.

18 Okada K, Hirono S, Kawai M, Miyazawa M, Shimizu A, Kitahata Y, Ueno M, Hayami S, Shimokawa T and Yamaue H: Prospective validation of patient fatigue questionnaire (FACITF) for fatigue assessment in nab-paclitaxel plus gemcitabine therapy. Mol Clin Oncol 8(1): 121-126, 2018.

19 Naito Y, Tamiya A, Tamiya M, Kimura Y, Hamaguchi M, Saijo N, Kanazu M, Tokura S, Shiroyama T, Morisita N, Omachi N, Suzuki H, Okamoto N, Okishio K, Hirashima T and Atagi S: Efficacy of nanoparticle albumin-bound paclitaxel regimens for relapsed small cell lung cancer: A retrospective analysis. Medicine (Baltimore) 96(35): e7884, 2017.
20 Hara Y, Sakagami H, Shi H, Abe T, Tamura N, Takeshima H, Horie N, Kaneko T, Shiratsuchi $\mathrm{H}$ and Kaneko T: Partial protection of paclitaxel-induced neurotoxicity by antioxidants. In Vivo 32: $\mathrm{xxx}-\mathrm{xxx}, 2018$.

21 Sakagami H, Tsuji M, Tomomura M, Masuda Y, Iwama S, Nakagawa M, Suzuki H, Tanaka K, Abe T, Tamura N, Tomomura A, Yokose S, Takeshima H, Natori T, Horiuchi M, Fujisawa T, Kiuchi Y, Oguchi K, Yasui T, Oizumi H and Oizumi $\mathrm{T}$ : Protection of differentiating neuronal cells from amyloid $\beta$ peptide-induced injury by alkaline extract of leaves of Sasa senanensis Rehder. In Vivo 32(2): 231-239, 2018.

22 Goodman and Gilman's The Pharmacological Basis of Therapeutics, 13th Edition. Section VIII Pharmacotherapy of Neoplastic Diseases. McGraw Hill. pp. 1159-1248, 2018.

Received March 19, 2018

Revised April 17, 2018

Accepted April 18, 2018 